\title{
KONSEKUENSI HASIL PENELITIAN TIM ICARUS TENTANG KELAJUAN NEUTRINO TERHADAP TEORI RELATIVITAS
}

\author{
Bertha Wikara \\ Pendidikan Sains Program Pascasarjana \\ Universitas Sebelas Maret \\ wikasih54@gmail.com
}

Perum Puri Kahuripan, C2, Jati, Jaten, Karanganyar 57731

\begin{abstract}
Abstrak
Penelitian ulang tim ICARUS atas kelajuan neutrino baru - baru ini mendapatkan hasil bahwa kelajuan neutrino sama dengan kelajuan cahaya. Hasil penelitian tersebut membawa konsekuensi tersendiri bagi ilmu fisika. Selama ini foton (cahaya) dianggap sebagai partikel tak bermassa, namun dalam eksperimen ICARUS ditemukan bahwa foton mempunyai kelajuan yang sama dengan neutrino yang merupakan partikel bermassa. Tidak mungkin sebuah partikel bermassa mempunyai kelajuan yang sama dengan partikel tidak bermassa. Seharusnya yang mempunyai massa lebih lambat kelajuannya dibanding yang tidak mempunyai massa. Oleh sebab itu foton seharusnya merupakan partikel yang mempunyai massa juga. Masalah lain muncul manakala rumus massa relativistik diterapkan untuk kasus neutrino. Oleh sebab neutrino mempunyai massa dan bergerak dengan kelajuan cahaya, maka nilai massa relativistiknya adalah tak terhingga. Namun ini bukan kenyataan yang dijumpai dalam eksperimen, jadi ada kesenjangan antara teori dan praktek. Cara menghilangkan kesenjangan tersebut adalah dengan menaikkan nilai konstanta $c^{2}$ dalam rumus massa relativistik. Namun hal ini membuat teori relativitas memprediksi bahwa ada yang bergerak lebih cepat dari cahaya di jagad raya.
\end{abstract}

Kata kunci : ICARUS, teori relativitas, foton, nilai konstanta $c^{2}$ 


\section{Pendahuluan}

Dunia fisika pada akhir tahun 2011 dikejutkan oleh penemuan tim OPERA di benua Eropa tentang kelajuan neutrino. Neutrino, sebuah partikel bermassa amat ringan yang tidak bermuatan listrik, ternyata memiliki kelajuan lebih tinggi daripada cahaya. Setelah mendeteksi waktu kedatangan pancaran - pancaran neutrino dari laboratorium CERN dekat Jenewa, Swiss ke laboratorium Gran Sasso, Italia, tim OPERA menemukan bahwa neutrino 60 nanodetik lebih cepat dari cahaya ${ }^{[1]}$. Hasil ini tidak serta - merta ditanggapi serius. Ada kalangan ilmuwan yang berpendapat bahwa hasil pengukuran tersebut mengalami kekeliruan. Mereka tidak yakin ada obyek yang mampu bergerak dengan kelajuan di atas kelajuan cahaya. Dasar penolakan ini adalah teori relativitas. Dalam teori tersebut cahaya dianggap sebagai obyek yang mempunyai kelajuan tertinggi di jagad raya. Tidak ada apapun yang mampu bergerak lebih cepat dari cahaya. Jika kelajuan neutrino benar benar melebihi kelajuan cahaya, maka massa, energi, ruang, dan waktu untuk neutrino menjadi tidak bisa ditentukan memakai teori relativitas. Hal ini menimbulkan kesulitan bagi teori tersebut dan dunia fisika pada umumnya.

Namun sebuah kabar baru datang pada pertengahan Maret 2012. ICARUS, sebuah tim peneliti yang beranggotakan sejumlah fisikawan, menyatakan telah menghitung ulang kelajuan neutrino dan mendapatkan hasil berbeda. Mereka menghitung ulang waktu kedatangan tujuh neutrino di laboratorium Gran Sasso yang berangkat dari laboratorium CERN, yang mana sebelumnya telah dihitung OPERA. Alat yang digunakan ICARUS lebih akurat daripada yang dipakai OPERA dalam eksperimen sebelumnya. ICARUS mendapatkan fakta bahwa secara kasar neutrino sama cepat dengan cahaya. Neutrino tidak lebih cepat 60 nanodetik seperti yang ditemukan OPERA, melainkan hanya 4 nanodetik saja ${ }^{[1][2][3]}$ (sumber lain ada yang mengatakan 0,3 nanodetik). Meskipun kelihatannya neutrino tetap lebih cepat dari cahaya, namun bisa dikategorikan sama cepat.

Para fisikawan pun menjadi lega mendengar berita tersebut. Ketidakyakinan mereka atas hasil penelitian tim OPERA kini memperoleh bukti. Mereka beranggapan bahwa teori relativitas berhasil terselamatkan. Namun perasaan lega tersebut ternyata semu belaka. Jika dicermati lebih jauh, hasil penelitian tim ICARUS pun menimbulkan konsekuensi besar bagi teori relativitas.

\section{Foton adalah Partikel Bermassa}

Konsekuensi pertama berkaitan dengan foton. Foton, sebuah partikel yang dihipotesiskan oleh Albert Einstein pada tahun 1905, selama ini dikenal sebagai partikel yang tidak mempunyai massa. Einstein mengajukan hipotesis foton untuk mengatasi masalah yang terdapat dalam suatu fenomena yang kini dikenal sebagai efek fotoelektrik. Pada tahun yang sama Einstein juga mempublikasikan makalahnya yang berjudul ' $\mathrm{Zur}$ Elektrodynamik Bewegter Korper', sebuah makalah yang berisi teori relativitas khusus $^{[4]}$. Teori ini membawa konsekuensi tersendiri bagi foton. Oleh sebab foton dinyatakan Einstein sebagai partikel cahaya, yang dengan demikian tentu saja bergerak dengan laju cahaya, maka mau tidak mau massa foton adalah nol nilainya $^{[5]}$. Keputusan ini didasarkan pada rumus massa relativistik yang ada pada teori relativitas khusus :

$$
m=\frac{m_{0}}{\sqrt{\left(1-v^{2} / c^{2}\right)}}
$$

Keterangan :

$M=$ massa benda saat bergerak/massa relativistik

$m_{0}=$ massa benda saat diam/massa diam

$v=$ kelajuan benda 
$c=$ laju cahaya di ruang hampa $\left(3 \times 10^{8}\right.$ $\mathrm{m} / \mathrm{s})^{[6]}$

Untuk foton, nilai $v$ pada rumus tersebut diisi dengan nilai kelajuan cahaya. Ini menyebabkan faktor pembagi dalam rumus massa relativistik menjadi nol nilainya. Jika nilai $m_{0}$ diisi dengan angka di atas nol, yang artinya foton mempunyai massa, maka nilai $m$ menjadi tak terhingga. Einstein menyadari bahwa ini bukan hal yang terbukti dalam prakteknya. Cahaya tidak menimbulkan dampak besar di lapangan. Oleh sebab itu ditarik kesimpulan bahwa nilai massa diam foton seharusnya adalah nol. Foton pun ditetapkan sebagai partikel tidak bermassa. Suatu gambaran yang dianggap aneh oleh fisikawan lain pada tahun 1905 karena pada masa itu ide tentang partikel tanpa massa merupakan gagasan baru yang bertentangan dengan logika. Berbeda dengan masa sekarang saat mekanika kuantum mengalami perkembangan pesat. Ide semacam itu sudah bukan hal aneh lagi.

Namun gagasan Einstein lambat laun bisa dipahami. Ide bahwa foton tidak mempunyai massa diterima dengan baik hingga satu abad lebih sejak kemunculannya. Namun pada maret 2012 tim ICARUS, kemungkinan tanpa disengaja, membuka konfirmasi baru untuk kasus tersebut lewat hasil penelitiannya. Dalam penghitungan kelajuan neutrino yang dibandingkan dengan kelajuan foton, didapatkan hasil bahwa kelajuan keduanya sama. Ini merupakan hasil yang ganjil. Neutrino merupakan partikel yang mempunyai massa, sedang foton tidak. Berdasarkan hal ini tidak mungkin kelajuan keduanya sama. Partikel yang mempunyai massa seharusnya bergerak lebih lambat daripada yang tidak mempunyai massa. Jika kelajuan neutrino dan foton sama berarti foton seharusnya mempunyai massa juga.

Neutrino sendiri awalnya juga dianggap partikel yang tidak mempunyai massa. Namun berdasarkan hasil eksperimen selanjutnya terbukti bahwa anggapan tersebut keliru. Penemuan ini diumumkan dalam konferensi fisika 'Neutrino 98' yang berlangsung di Jepang tanggal 5 Juni 1998. Menurut laporan yang dikemukakan dalam konferensi tersebut neutrino ternyata mempunyai massa. Detektor neutrino menunjukkan bahwa neutrino mampu berosilasi dari satu flavor ke flavor yang lain. Hal ini hanya bisa terjadi bila neutrino mempunyai massa. Laporan tersebut dinyatakan oleh satu tim internasional yang tergabung dalam eksperimen Super-Kamiokande. Tim tersebut telah melakukan penelitian terhadap data - data yang dikumpulkan selama setahun oleh laboratorium penelitian bawah tanah di Jepang ${ }^{[7]}$.

Fenomena neutrino, yang sebelumnya dianggap partikel tak bermassa namun terbukti bermassa, menunjukkan bahwa kekeliruan bisa saja terjadi dalam kasus massa foton. Hasil eksperimen ICARUS mengindikasikan hal tersebut.

\section{Penaikan Nilai Konstanta dalam Rumus Massa Relativistik \\ Konsekuensi kedua dari hasil} penelitian tim ICARUS berhubungan dengan nilai konstanta $c^{2}$ dalam rumus massa relativistik. Didepan sudah dijelaskan bahwa neutrino mempunyai massa dan bergerak dengan laju cahaya. Dengan demikian bila nilai massa relativistik neutrino dihitung, maka didapatkan nilai tak terhingga. Sudah merupakan suatu keharusan dalam sains bahwa teori mesti selaras dengan praktek. Oleh sebab itu jika hasil penghitungan massa relativistik menunjukkan nilai tak terhingga, maka dalam prakteknya harus pula dijumpai kenyataan demikian. Namun kenyataannya tidak. Bila memang benar massa relativistik neutrino adalah tak terhingga tentu menimbulkan dampak yang amat besar bagi lingkungannya.

Angka tak terhingga pada nilai massa relativistik selama ini dianggap sebagai 
limit nilai massa tertinggi untuk benda yang sedang bergerak. Bila suatu benda (massa) bergerak dengan laju cahaya, maka nilai massa relativistiknya adalah tak terhingga, tidak peduli seberapa nilai massa diamnya. Akibatnya, energi yang digunakan oleh benda tersebut untuk bergerak menjadi tak terhingga pula besarnya. Hal ini merupakan sesuatu yang mustahil. Oleh karena itu tidak mungkin suatu massa dapat bergerak hingga mencapai laju cahaya. Satu - satunya yang mampu mencapai laju cahaya adalah partikel cahaya itu sendiri atau dengan kata lain foton. Hal ini bisa terjadi sebab foton tidak mempunyai massa.

Ketidakselarasan antara teori dan praktek dalam kasus nilai massa relativistik neutrino harus diatasi supaya rumus massa relativistik bisa dipercaya kembali untuk menggambarkan hasil eksperimen. Rumus yang menunjukkan gambaran tidak sesuai dengan hasil eksperimen bakal ditinggalkan oleh penganutnya. Cara yang tepat untuk mengatasi problem tadi adalah dengan menaikkan nilai konstanta $c^{2}$ dalam rumus massa relativistik. Nilai konstanta ini tidak lain adalah laju cahaya yang telah dikuadratkan dan diletakkan sebagai pembagi untuk kelajuan benda yang telah dikuadratkan pula. Nilai konstanta 1 dalam rumus massa relativistik tidak boleh diutak - atik karena akan membuat hasil perhitungan tidak presisi lagi. Bila nilai konstanta 1 diturunkan atau dinaikkan nilainya, maka nilai massa relativistik untuk sebuah massa yang tidak bergerak menjadi berbeda dengan nilai massa diamnya.

Untuk lebih memahami penjelasan berikut silakan mencermati rumus massa relativistik yang telah disajikan sebelumnya. Bila nilai $c^{2}$ dinaikkan sedikit, atau dalam kalimat lain diberi selisih terhadap kecepatan neutrino, maka nilai massa relativistik neutrino akan terhindar dari angka tak terhingga. Nilai massa relativistik tersebut akan kembali normal seperti nilai massa biasa. Inilah pemecahan yang ideal untuk problem nilai massa relativistik tak terhingga tadi. Namun langkah pemecahan ini ternyata menimbulkan masalah baru. Menaikkan nilai laju cahaya seenaknya seperti yang baru saja dilakukan menyalahi hasil eksperimen penghitungan laju cahaya. Laju cahaya sudah ditetapkan berdasarkan hasil eksperimen, yaitu $299.792 .458 \mathrm{~m} / \mathrm{s}$, atau demi kepraktisan kadang dibulatkan menjadi $300.000 .000 \mathrm{~m} / \mathrm{s}^{[8][9]}$. Tidak bisa seenaknya menambah sendiri nilai laju cahaya. Memang benar bahwa kelajuan cahaya tidak selalu sama bila merambat dalam berbagai macam medium, namun hal itu tidak masalah karena yang diambil sebagai konstanta disini adalah kelajuan cahaya saat melintasi ruang hampa. Itu merupakan kelajuan cahaya yang asli.

Karena terbentur pada problem diatas, maka nilai konstanta pada rumus massa relativistik sebaiknya diganti bukan laju cahaya. Namun jika demikian yang diinginkan, maka harus dicari obyek yang mampu bergerak lebih cepat dari cahaya, karena seperti yang telah dijelaskan didepan nilai konstanta harus dinaikkan. Tetapi hal ini tentu bertentangan dengan teori relativitas yang menganggap cahaya sebagai obyek tercepat di jagad raya.

Kesulitan lain akan muncul saat nilai konstanta dalam rumus massa relativistik dinaikkan menjadi diatas $c^{2}$. Kesulitan tersebut tampak pada kasus sebagai berikut. Ada dua benda, A dan B, bergerak saling mendekat dalam lintasan lurus dan kecepatan keduanya konstan. Masing masing benda tersebut bergerak dengan kecepatan $c$. Berdasarkan teori relativitas khusus, menurut pengamat di A, B bergerak dengan kecepatan :

$$
\begin{aligned}
& v=\frac{(c+c)}{\left(1+(c . c) / c^{2}\right)} \\
& v=\frac{2 c}{2} \\
& v=c
\end{aligned}
$$


Begitu pula jika kecepatan A diukur oleh pengamat di B. Kecepatan A didapati sama dengan kecepatan cahaya ${ }^{[10]}$.

Hasil penghitungan yang berlainan tampak bila nilai konstanta diatas, yaitu $c^{2}$, dinaikkan nilainya umpama menjadi $c^{2}+1$. Akibatnya, hasil penghitungan kecepatan A maupun B tadi menjadi naik pula. Kini kelajuan keduanya menjadi diatas kelajuan cahaya. Hal ini tentu saja tidak mungkin menurut teori relativitas. Tidak ada obyek apapun, termasuk informasi (dalam hal ini adalah hasil pengamatan dengan cara seperti diatas) yang bergerak lebih cepat dari cahaya. Perlu diingat bahwa meskipun rumus barusan bukanlah rumus massa relativistik, namun nilai konstantanya harus ikut dinaikkan bila nilai konstanta pada rumus massa relativistik dinaikkan.

Hasil diatas menimbulkan dilema. Jika nilai konstanta $c^{2}$ tidak dinaikkan, maka akan terjadi kesenjangan antara teori dan praktek. Neutrino secara teori mempunyai nilai massa relativistik tak terhingga, namun dalam eksperimen tidak terbukti demikian. Tetapi jika konstanta $c^{2}$ dinaikkan, berarti teori relativitas mengakui ada yang bergerak lebih cepat dari cahaya di jagad raya.

\section{Kesimpulan}

Hasil penelitian ICARUS tentang kelajuan neutrino yang diumumkan pada bulan Maret 2012 menimbulkan konsekuensi bagi teori relativitas. Kelajuan neutrino yang dinyatakan sama cepat dengan cahaya ternyata menimbulkan kesulitan baru bagi teori tersebut. Kesulitan yang dimaksud berkaitan dengan nilai massa foton serta nilai konstanta $c^{2}$.

Neutrino telah ditemukan mempunyai kelajuan sama dengan cahaya, namun fakta bahwa keduanya berbeda dalam hal nilai massa menyebabkan tanda tanya. Neutrino mempunyai massa, sedang foton tidak. Tidak mungkin sesuatu yang mempunyai massa mampu sama cepat dengan sesuatu yang tidak mempunyai massa. Berdasarkan hal ini disimpulkan bahwa foton pun seharusnya mempunyai massa.

Neutrino mempunyai massa dan bergerak dengan kelajuan cahaya. Konsekuensinya bila nilai massa relativistiknya dihitung akan didapatkan angka tak terhingga. Nilai tak terhingga tersebut seharusnya membawa dampak besar di lapangan, namun kenyataannya tidak. Dengan demikian disimpulkan terjadi kesenjangan antara teori dan praktek pada kasus tersebut. Nilai tak terhingga bukan nilai yang kenyataannya dijumpai dalam praktek, oleh sebab itu harus dieliminasi. Cara untuk mengeliminasi nilai tersebut adalah dengan menaikkan nilai konstanta $c^{2}$ dalam rumus massa relativistik. Bila nilai konstanta tersebut dinaikkan, maka nilai konstanta yang sama untuk rumus lain dalam teori relativitas harus pula dinaikkan.

Kenaikan nilai konstanta tadi dalam teori relativitas akan menyebabkan timbulnya hal yang seharusnya dihindari dalam teori tersebut, yaitu prediksi bahwa ada yang bisa bergerak lebih cepat dari cahaya. Namun konsekuensi ini merupakan sesuatu yang tidak bisa ditolak karena hasil eksperimen ICARUS, awal penyebab dari prediksi ini, menjadi bukti harus dilakukannya perubahan pada nilai konstanta tersebut.

\section{Daftar Acuan}

[1] http://www.nature.com/news/neutrinosnot-faster-than-light-1.10249/3 April 2012.

[2] http://www.sciencedaily.com/releases/2 012/03/120316204743.htm/3 April 2012.

[3]http://arxiv.org/abs/1203.3433/9 April 2012.

[4]Wikara, B. (2011), "Penafsiran Ulang Prinsip Kesetaraan Massa-Energi untuk Memperluas Cakupan Teori Relativitas Sebagai Dasar Pencapaian Teori Segalanya", Prosiding Seminar Nasional Fisika \& Pendidikan Sains,Peningkatan Kualitas Pendidikan 
Sains Berbasis Karakter, Surakarta : Program Pendidikan Fisika PMIPA FKIP Universitas Sebelas Maret.

[5]Muljono. (2003), Fisika Modern, Penerbit Andi, Yogyakarta.

[6]Krane S. K. (2006), Fisika Modern (penerjemah : H. J. Wospakrik), Penerbit Universitas Indonesia, Jakarta.

[7]http://www.fisikanet.lipi.go.id/utama.cg i? cetakartikel\&897152400/4 Maret 2011.
[8]Tipler A. P. (1998), Fisika untuk Sains dan Teknik (penerjemah : L. Prasetio \& R. W. Adi), Penerbit Erlangga, Jakarta.

[9]Giancoli C. D. (1999), Fisika (penerjemah : Y. Hanum), Penerbit Erlangga, Jakarta.

[10]Gribbin J. (2005), Fisika Modern (penerjemah : Dimas H), Penerbit Erlangga, Jakarta. 